\title{
Camel Milk Modulates the Expression of Aryl Hydrocarbon Receptor-Regulated Genes, Cyp1a1, Nqo1, and Gsta1, in Murine hepatoma Hepa 1c1c7 Cells
}

\author{
Hesham M. Korashy, ${ }^{1}$ Mohamed A. M. El Gendy, ${ }^{2}$ \\ Abdulqader A. Alhaider, ${ }^{3}$ and Ayman O. El-Kadi ${ }^{2}$ \\ ${ }^{1}$ Department of Pharmacology and Toxicology, College of Pharmacy, King Saud University, 11451 Riyadh, Saudi Arabia \\ ${ }^{2}$ Faculty of Pharmacy \& Pharmaceutical Sciences, University of Alberta, Edmonton, AB, Canada T6G 2E1 \\ ${ }^{3}$ Department of Pharmacology, College of Medicine, King Saud University, 11461 Riyadh, Saudi Arabia
}

Correspondence should be addressed to Ayman O. El-Kadi, aelkadi@pharmacy.ualberta.ca

Received 6 September 2011; Revised 24 October 2011; Accepted 8 November 2011

Academic Editor: Ikhlas A. Khan

Copyright (C) 2012 Hesham M. Korashy et al. This is an open access article distributed under the Creative Commons Attribution License, which permits unrestricted use, distribution, and reproduction in any medium, provided the original work is properly cited.

\begin{abstract}
There is a traditional belief in the Middle East that camel milk may aid in prevention and treatment of numerous cases of cancer yet, the exact mechanism was not investigated. Therefore, we examined the ability of camel milk to modulate the expression of a wellknown cancer-activating gene, Cytochrome P450 la1 (Cyp1a1), and cancer-protective genes, NAD(P)H:quinone oxidoreductase 1 (Nqo1) and glutathione S-transferase al (Gsta1), in murine hepatoma Hepa 1c1c7 cell line. Our results showed that camel milk significantly inhibited the induction of Cypla1 gene expression by 2,3,7,8-tetrachlorodibenzo-p-dioxin (TCDD), the most potent Cyplal inducer and known carcinogenic chemical, at mRNA, protein, and activity levels in a concentration-dependent manner. In addition, camel milk significantly decreased the xenobiotic responsive element (XRE)-dependent luciferase activity, suggesting a transcriptional mechanism is involved. Furthermore, this inhibitory effect of camel milk was associated with a proportional increase in heme oxygenase 1. On the other hand, camel milk significantly induced Nqo1 and Gsta1 mRNA expression level in a concentration-dependent fashion. The RNA synthesis inhibitor, actinomycin D, completely blocked the induction of Nqo1 mRNA by camel milk suggesting the requirement of de novo RNA synthesis through a transcriptional mechanism. In conclusion, camel milk modulates the expression of Cypla1, Nqo1, and Gstal at the transcriptional and posttranscriptional levels.
\end{abstract}

\section{Introduction}

The aryl hydrocarbon receptor (AhR), a cytosolic ligandactivated transcriptional factor, belongs to the basic-helixloop-helix (bHLH)/Per-ARNT-Sim (PAS) family of transcription proteins, which are involved in regulation of cell differentiation and proliferation $[1,2]$. Mechanistically, AhR is located in the cytoplasm bound with heat shock protein-90 (HSP90) and AhR interacting protein (AIP) forming inactive complex. Activation of AhR upon binding with its ligands, such as 2,3,7,8-tetrachlorodibenzo- $p$-dioxin (TCDD), a polycyclic aromatic hydrocarbon (PAH), causes dissociation of HSP90 and AIP from the activated ligandreceptor complex, subsequently leading to translocation of the complex into nucleus. In the nucleus, the ligand-receptor complex dimerizes with AhR nuclear translocator (ARNT), which subsequently binds to xenobiotic-responsive element (XRE) located in the promoter region of so-called AhRregulated genes resulting in promoting its transcription and protein translation processes $[3,4]$.

The AhR-regulated gene batteries include phase I xenobiotic metabolizing enzymes such as the cytochrome P450 1A1 (CYP1A1), CYP1A2, CYP1B1 and phase II enzymes such as $\mathrm{NAD}(\mathrm{P}) \mathrm{H}$ :quinone oxidoreductase 1 (NQO1), glutathione S-transferase A1 (GSTA1), uridine diphosphate glucuronosyltransferase $1 \mathrm{~A} 6$, and aldehyde dehydrogenase-3 $[3,4]$. Among these genes, CYP1A1 plays a particular role in bioactivating procarcinogens into carcinogen and toxic 
metabolites and hence is considered as cancer-activating gene [5], whereas the NQO1 and GSTA1 catalyze reduction of several environmental contaminants and endogenous compounds that maintain endogenous antioxidants, such as ubiquinone and vitamin $\mathrm{E}$, to protect tissues against mutagens, carcinogens, and oxidative stress damage $[6,7]$. Accordingly, one of the strategies for protecting human cells and tissues from the toxic effects of carcinogenic and cytotoxic metabolites generally include attenuation of the carcinogen-activating genes, CYP1A1 signaling pathways, and/or enhancing the adaptive mechanisms by increasing the expression of detoxification and antioxidant genes, such as NQO1 and GSTA1 [8].

Chemoprevention by dietary constituents in the form of functional food has a well-established beneficial role in health promotion and emerged as a novel approach to control cancers [9]. Camel's milk is different from other ruminant milk, having low cholesterol, lactoferrin, low sugar, high minerals (sodium, potassium, iron, copper, zinc and magnesium), high vitamin C, B2, A, and E, low protein, and high concentrations of insulin. Recent studies have reported that camel milk is the most active milk among other species against E. coli, Staphylococcus aureus, Salmonella typhimurium, and rotavirus [10, 11]. In addition, it has been demonstrated that milk, in addition to secretory IgA and IgM, also contains numerous nonantibody components that possess antiviral activity, including lactoferrin [10].

Until recently, it is traditionally claimed that drinking camel milk may help to fight against serious diseases and cure numerous cases of cancer; however, this claim has never been exposed to scientific scrutiny investigation. Therefore, the main objective of the current study was to explore the capacity of camel milk to modulate the expression of Cypla1, Nqo1, and Gstal genes as target for cancer prevention in murine hepatoma Hepa 1c1c7 cells.

\section{Materials and Methods}

2.1. Materials. 7-Ethoxyresorufin (7ER), Dulbecco's Modified Eagle's Medium (DMEM), protease inhibitor cocktail, sulforaphane (SNF), resveratrol (RES), 3-(4,5-dimethylthiazol-2-yl)-2,5-diphenyltetrazolium bromide (MTT), and rabbit anti-goat IgG peroxidase secondary antibody were purchased from Sigma-Aldrich (St. Louis, MO). 2,3,7,8Tetrachlorodibenzo- $p$-dioxin, $>99 \%$ pure, was purchased from Cambridge Isotope Laboratories (Woburn, MA). Resorufin and $100 \times$ vitamin supplements were purchased from ICN Biomedicals Canada (Montreal, QC). TRIzol and Lipofectamine 2000 reagents were purchased from Invitrogen (Carlsbad, CA). The High-Capacity cDNA reverse transcription kit and SYBR Green PCR Master Mix were purchased from Applied Biosystems (Foster City, CA). Actinomycin D (Act-D) was purchased from Calbiochem (San Diego, CA). Dual-Luciferase Reporter Assay System was obtained from Promega Corporation (Madison, WI). Chemiluminescence Western blotting detection reagents were obtained from GE Healthcare Life Sciences (Piscataway,
NJ). Nitrocellulose membrane was purchased from BioRad Laboratories (Hercules, CA). Cyplal goat anti-mouse polyclonal primary antibody, glyceraldehyde-3-phosphate dehydrogenase (Gapdh) rabbit anti-goat polyclonal antibody, and anti-rabbit IgG peroxidase secondary antibodies were purchased from Santa Cruz Biotechnology (Santa Cruz, CA). All other chemicals were purchased from Fisher Scientific Co. (Toronto, ON).

2.2. Milk Sample Collection and Preparation. Camel milk was collected aseptically from five healthy domestic camels (Camelus dromedaries). The camel milk was collected from farm and desert living animals. The collection of milk was usually conducted during the feeding time and was performed by experienced attendants. Milk was allowed to flow directly into sterile stainless steel containers and then transferred to glass vials. Camel samples were transported to the laboratory as soon as practical $(<4 \mathrm{~h})$ and were frozen at $-80^{\circ} \mathrm{C}$. Aqueous portion (fat-free, skimmed milk) was removed from the lipids (cream) as described before [12]. Briefly, aliquots of pooled milk samples were centrifuged at $1400 \times \mathrm{g}$ for 30 minutes at $4^{\circ} \mathrm{C}$, thereafter, the creamy layer consisting largely of fat was removed by filtration through a glass wool plug in a Pasteur pipette. Camel milk was collected and kept in $-80^{\circ} \mathrm{C}$ freezer until use.

2.3. Cell Culture and Treatments. Murine hepatoma Hepa 1c1c7 cells (American Type Culture Collection, Manassas, VA) were maintained in DMEM, without phenol red supplemented with $10 \%$ heat-inactivated fetal bovine serum, $20 \mu \mathrm{M}$ L-glutamine, $100 \mathrm{IU} / \mathrm{mL}$ penicillin, $10 \mu \mathrm{g} / \mathrm{mL}$ streptomycin, $0.1 \mathrm{mM}$ nonessential amino acids, and vitamin supplement solution. Cells were grown in $75 \mathrm{~cm}^{2}$ tissue culture flasks at $37^{\circ} \mathrm{C}$ under a $5 \% \mathrm{CO}_{2}$ humidified environment.

Hepa 1c1c7 cells were plated onto 96- and six-well cell culture plates in DMEM culture media for the mRNA, protein, and catalytic activity assays. In all experiments, the cells were pretreated for indicated time interval in serumfree media with various concentrations of camel milk in the presence or absence of TCDD as indicated. Stock solutions of TCDD were prepared in dimethyl sulfoxide (DMSO) and stored at $-20^{\circ} \mathrm{C}$, in which the concentration of DMSO did not exceed $0.05 \%(\mathrm{v} / \mathrm{v})$.

2.4. Cytotoxicity of Camel Milk. The effects of camel milk (fat-free) on Hepa 1c1c7 cell viability were determined by measuring the capacity of reducing enzymes present in viable cells to convert MTT salt to formazan crystals as described previously [13]. Twenty-four hours after incubating the cells with the tested milk in the presence and absence of TCDD in a 96-well cell culture plate at $37^{\circ} \mathrm{C}$ under a $4 \% \quad \mathrm{CO}_{2}$ humidified incubator, the media were removed and a $100 \mu \mathrm{L}$ of serum-free medium containing $1.2 \mathrm{mM}$ of MTT dissolved in phosphate-buffered-saline (PBS), $\mathrm{pH} 7.4$, was added to each well. The plate was then incubated in a $\mathrm{CO}_{2}$ incubator at $37^{\circ} \mathrm{C}$ for $2 \mathrm{~h}$. The media were then decanted off by inverting the plate, and a $100 \mu \mathrm{L}$ of isopropyl alcohol was added to each well, with shaking for $1 \mathrm{~h}$ to dissolve the formazan 
TABle 1: Primers sequences used for Real-Time PCR reactions.

\begin{tabular}{lcc}
\hline Gene & Forward primer & Reverse primer \\
\hline Cyplal & 5'-GGT TAA CCA TGA CCG GGA ACT-3' & 5'-TGC CCA AAC CAA AGA GAG TGA-3' \\
Ho-1 & 5'-GTG ATG GAG CGT CCA CAG C-3' & 5'-TGG TGG CCT CCT TCA AGG-3' \\
Nqol & 5'-GGA AGC TGC AGA CCT GGT GA-3' & 5'-CCT TTC AGA ATG GCT GGC A-3' \\
Gstal & 5'-CCC CTT TCC CTC TGC TGA AG-3' & 5'-TGC AGC TTC ACT GAA TCT TGA AAG-3' \\
$\beta$-actin & 5'-TAT TGG CAA CGA GCG GTT CC-3' & 5'-GGC ATA GAG GTC TTT ACG GAT GTC-3' \\
\hline
\end{tabular}

crystals. The color intensity in each well was measured at wavelength of 550 using BIO-TEK Instruments EL 312e microplate reader, Bio-Tek Instruments (Winooski, VT). The percentage of cell viability was calculated relative to control wells designated as $100 \%$ viable cells.

2.5. Determination of Cyp1a1 Enzymatic Activity. Cypla1dependent 7-ethoxyresorufin (7ER) O-deethylase (EROD) activity was performed on intact living Hepa 1c1c7 cells using 7ER as a substrate [14]. After incubation of the cells with increasing concentrations of fat-free camel milk for $24 \mathrm{~h}$, media were aspirated and the cell monolayers were rinsed with PBS. Thereafter, $100 \mu \mathrm{L}$ of $2 \mu \mathrm{M}$ 7ER in assay buffer $(0.05 \mathrm{M}$ Tris, $0.1 \mathrm{M} \mathrm{NaCl}, \mathrm{pH} 7.8)$ was then added to each well. Immediately, an initial fluorescence measurement $(t=0)$ at excitation/emission $(545 \mathrm{~nm} / 575 \mathrm{~nm})$ was recorded from each well using Baxter 96-well fluorometer (Deerfield, IL). The plates were then replaced in the incubator, and additional set of fluorescence measurements of the wells were recorded every $5 \mathrm{~min}$ for $20 \mathrm{~min}$ interval. The amount of resorufin formed in each well was determined by comparison with a standard curve of known concentrations. The working solution was then aspirated, the cells were rinsed twice with PBS, and $50 \mu \mathrm{l}$ of double de-ionized water was added to lyse the cells. After placing of the cell plates at $-80^{\circ} \mathrm{C}$ for $30 \mathrm{~min}$, the cell lysates were allowed to thaw, and protein levels were determined using a modified fluorescent assay [15]. The rate of resorufin formation was expressed as $\mathrm{pmol} / \mathrm{min} / \mathrm{mg}$ protein.

2.6. RNA Extraction and cDNA Synthesis. Total RNA was isolated using TRIzol reagent (Invitrogen) according to the manufacturer's instructions and quantified by measuring the absorbance at $260 \mathrm{~nm}$. RNA quality was determined by measuring the 260/280 ratio. Thereafter, first strand cDNA was synthesized using the High-Capacity cDNA reverse transcription kit (Applied Biosystems) according to the manufacturer's instructions. Briefly, $1 \mu \mathrm{g}$ of total RNA from each sample was added to a mix of $2.0 \mu \mathrm{L}$ of $10 \mathrm{x}$ reverse transcriptase buffer, $0.8 \mu \mathrm{L}$ of $25 \mathrm{x}$ dNTP mix $(100 \mathrm{mM})$, $2.0 \mu \mathrm{L}$ of $10 \mathrm{x}$ reverse transcriptase random primers, $1.0 \mu \mathrm{L}$ of MultiScribe reverse transcriptase, and $3.2 \mu \mathrm{L}$ of nuclease-free water. The final reaction mix was kept at $25^{\circ} \mathrm{C}$ for $10 \mathrm{~min}$, heated to $37^{\circ} \mathrm{C}$ for $120 \mathrm{~min}$, heated for $85^{\circ} \mathrm{C}$ for $5 \mathrm{~s}$, and finally cooled to $4^{\circ} \mathrm{C}[16]$.

2.7. Quantification of mRNA Expression by Real-Time Polymerase Chain Reaction (RT-PCR). Quantitative analysis of specific mRNA expression was performed by RT-PCR by subjecting the resulting cDNA to PCR amplification using 96-well optical reaction plates in the ABI Prism 7500 System (Applied Biosystems). The $25 \mu \mathrm{L}$ reaction mix contained $0.1 \mu \mathrm{L}$ of $10 \mu \mathrm{M}$ forward primer and $0.1 \mu \mathrm{L}$ of $10 \mu \mathrm{M}$ reverse primer ( $40 \mathrm{nM}$ final concentration of each primer), $12.5 \mu \mathrm{L}$ of SYBR Green Universal Master Mix, $11.15 \mu \mathrm{L}$ of nucleasefree water, and $1.25 \mu \mathrm{L}$ of $\mathrm{cDNA}$ sample. The primers used in the current study (Table 1) $[17,18]$ were purchased from Integrated DNA Technologies (IDT, Coralville, IA). Assay controls were incorporated onto the same plate, namely, no-template controls to test for the contamination of any assay reagents. The RT-PCR data was analyzed using the relative gene expression (i.e., $\Delta \Delta C T$ ) method, as described in Applied Biosystems User Bulletin [19]. The data are presented as the fold change in gene expression normalized to the endogenous housekeeping gene $(\beta$-actin) and was determined using the equation: fold change $=2^{-\Delta(\Delta C t)}$, where $\Delta C t=C t_{\text {(target) }}-C t_{(\beta \text {-actin })}$ and $\Delta(\Delta C t)=\Delta C t_{\text {(treated })}-$ $\Delta C t_{\text {(untreated) }}$.

2.8. Protein Extraction and Western Blot Analysis. Twentyfour hours after incubating the cells with increasing concentrations of camel milk (fat-free), the cells were washed once with cold PBS and collected by scraping in $100 \mu \mathrm{L}$ of lysis buffer ( $50 \mathrm{mM}$ HEPES, $0.5 \mathrm{M} \mathrm{NaCl}$, $1.5 \mathrm{mM} \mathrm{MgCl}, 1 \mathrm{mM}$ EDTA, $10 \%$ (v/v) glycerol, $1 \%$ Triton X-100, and $5 \mu \mathrm{L} / \mathrm{mL}$ of protease inhibitor cocktail). The lysates were incubated on ice for $1 \mathrm{~h}$ with intermittent vortexing every $10 \mathrm{~min}$, followed by centrifugation at $12,000 \times \mathrm{g}$ for $10 \mathrm{~min}$ at $4^{\circ} \mathrm{C}$. The supernatant was then stored at a $-80^{\circ} \mathrm{C}$ freezer for later use in the Western blot analysis.

Western blot analysis was performed as described previously [20]. For Cyp1a1 immuno-detection, $30 \mu \mathrm{g}$ of proteins from each treatment group were diluted with same amount $(1: 1)$ of $2 \mathrm{X}$ loading buffer $(0.1 \mathrm{M}$ Tris- $\mathrm{HCl}, \mathrm{pH}$ $6.8,4 \%$ SDS, $1.5 \%$ bromophenol blue, $20 \%$ glycerol, $5 \% \beta$ mercaptoethanol), boiled and loaded onto a 10\% SDSpolyacrylamide gel. Samples were electrophoresed at $120 \mathrm{~V}$ for $2 \mathrm{~h}$, and the separated proteins were transferred to Trans-Blot nitrocellulose membrane $(0.45 \mu \mathrm{m})$ in a buffer containing $25 \mathrm{mM}$ Tri- $\mathrm{HCl}, 192 \mathrm{mM}$ glycine, and 20\% (v/v) methanol. Protein blots were blocked overnight at $4^{\circ} \mathrm{C}$ in a solution containing $5 \%$ skim milk powder, $2 \%$ bovine serum albumin, and $0.5 \%$ Tween-20 in TBS solution $(0.15 \mathrm{M}$ $\mathrm{NaCl}, 3 \mathrm{mM} \mathrm{KCl}, 25 \mathrm{mM}$ Tris-base). Thereafter, the blocking solution was removed and the blots were rinsed three times 
in a wash buffer $(0.1 \%$ Tween-20 in TBS). Proteins were detected by incubation with a primary polyclonal goat antimouse Cyplal antibody for $2 \mathrm{~h}$ at $4^{\circ} \mathrm{C}$ in TBS containing $0.01 \%$ sodium azide and $0.05 \%$ Tween-20. The primary antibody solution was removed and blots were rinsed three times with a wash buffer, followed by incubation with horseradish peroxidase-conjugate rabbit anti-goat secondary antibody for $1 \mathrm{~h}$ at room temperature followed by washing as previously described. Antibody detection was performed using the enhanced chemiluminescence method. The intensity of Cypla1 bands was quantified, relative to the signals obtained for Gapdh, using Java-based image-processing software, Image (W. Rasband (2005) National Institutes of Health, Bethesda, MD, http://rsb.info.nih.gov/ij/).

2.9. Transient Transfection and Luciferase Assay. Transient transfection and luciferase assay were carried out as described previously [21]. Briefly, Hepa 1 c1c7 cells $\left(3 \times 10^{4}\right.$ cells per well) were plated onto 12 -well cell culture plates. Each well was cotransfected with $1.5 \mu \mathrm{g}$ of XRE-driven luciferase reporter plasmid pGudLuc 1.1 and $0.1 \mu \mathrm{g}$ of the renilla luciferase pRL-CMV vector, used for normalization. The pGudLuc 1.1 plasmid was provided as a gift from Dr. Michael S. Denison (University of California, Davis, CA), while pRL-CMV vector was obtained from Promega Corporation (Madison,WI). Transfection procedure was carried out using Lipofectamine 2000 reagent according to the manufacturer's instructions (Invitrogen), the luciferase assay was performed according to the manufacturer's instructions (Promega), and luciferase activity was reported as relative light unit of firefly luciferase to renilla luciferase (Fluc/Rluc).

2.10. Statistical Analysis. All results are presented as mean \pm SEM. The comparative analysis of the results from various experimental groups with their corresponding controls was performed using SigmaStat for Windows, Systat Software Inc., (San Jose, CA). One-way analysis of variance (ANOVA) followed by Student-Newman-Keul's test was carried out to assess the significant difference between different groups. The differences were considered significant when $P<0.05$.

\section{Results}

3.1. Effect of Camel Milk on Hepa 1clc7 Cell Viability. To determine the cellular toxicity effects of camel milk (fatfree) in the presence and absence of TCDD on Hepa 1c1c7, cells were treated for $24 \mathrm{~h}$ with increasing concentrations of camel milk $(0,15,25,50,100$, and $200 \mu \mathrm{L} / \mathrm{mL})$ in the presence and absence of TCDD $(1 \mathrm{nM})$ and the cell viability was determined by MTT assay. Figure 1 shows that neither camel milk alone nor with TCDD were toxic to Hepa 1c1c7 cells at all concentrations of camel milk used, with the exception of mixture of TCDD plus camel milk $(200 \mu \mathrm{L} / \mathrm{mL})$ that significantly decreased cell viability by approximately $25 \%$. Based on these results, concentrations of 0,25 , and $100 \mu \mathrm{L} / \mathrm{mL}$ of fat-free camel milk in the presence and absence of TCDD were chosen to be used in the subsequent experiments.

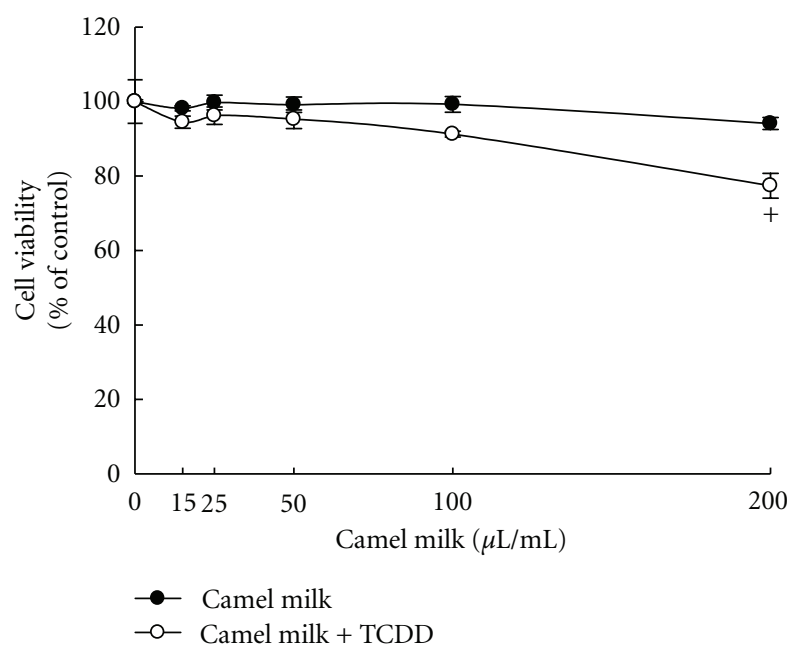

FIGURE 1: Effect of camel milk on Hepa 1c1c7 cell viability. Hepa $1 \mathrm{c} 1 \mathrm{c} 7$ cells were incubated for $24 \mathrm{~h}$ with various concentrations of fat-free camel milk $(0,15,25,50,100$, and $200 \mu \mathrm{L} / \mathrm{mL})$ in the presence and absence of TCDD $(1 \mathrm{nM})$. Thereafter, cell viability was assessed using the MTT assay. Values are presented as percentage of the control (mean \pm SEM, $n=8$ ). ${ }^{*} P<0.05$ compared with control (concentration $=0 \mu \mathrm{L} / \mathrm{mL}$, nontreated cells).

3.2. Effect of Camel Milk on the TCDD-Mediated Induction of Cypla1 Catalytic Activity in Hepa 1c1c7 Cells. To determine the capacity of camel milk to alter the induction of Cyplal catalytic activity by TCDD, Hepa 1c1c7 cells were preincubated with increasing concentrations of camel milk (fat-free) $(0,25$, and $100 \mu \mathrm{L} / \mathrm{mL})$ or RES $(25 \mu \mathrm{M})$, a positive control, for $30 \mathrm{~min}$ before the incubation with $1 \mathrm{nM}$ TCDD for additional $24 \mathrm{~h}$. The TCDD $1 \mathrm{nM}$ concentration was selected from our previous concentration-response study that caused maximum induction of Cyplal gene without significant cell toxicity [22]. Thereafter, Cyplal activity was determined by EROD assay. Figure 2 shows that TCDD alone markedly induced Cyplal enzymatic activity level by 180 -fold. Furthermore, camel milk at all concentrations tested significantly inhibited the TCDD-mediated induction of Cypla1 activity by approximately $63 \%$ and $80 \%$ at the concentrations of 25 and $100 \mu \mathrm{L} / \mathrm{mL}$, respectively, (Figure 2). On the other hand, RES, a well-known AhR antagonist, significantly reduced the Cyplal induction by TCDD (Figure 2). The observed inhibition of Cyp1a1 by camel milk (fat-free) particularly at the highest concretion is due to a direct effect of camel milk and not because of any cell toxicity (Figure 1).

3.3. Effect of Camel Milk on the TCDD-Mediated Induction of Cyplal mRNA Level in Hepa 1clc7 Cells. To determine whether the inhibitory effect of camel milk (fat-free) on the TCDD-mediated induction of Cyplal activity (Figure 2) is attributed to a transcriptional mechanism, Cypla1 mRNA levels were determined in Hepa 1c1c7 cells treated for $6 \mathrm{~h}$ with TCDD $(1 \mathrm{nM})$ in the presence and absence of different concentrations of camel milk $(0,25$, and $100 \mu \mathrm{L} / \mathrm{mL})$ or RES $(25 \mu \mathrm{M})$ as positive control. Our results showed that 


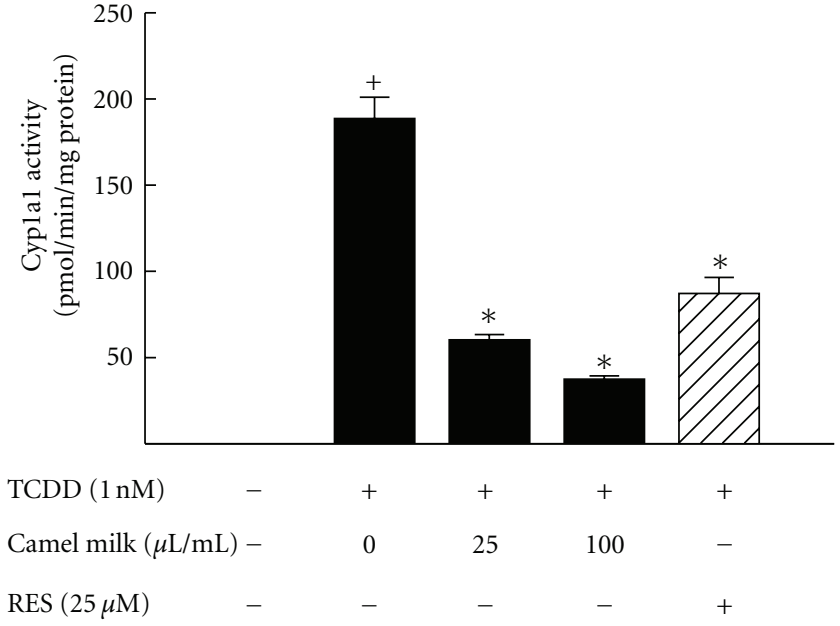

Figure 2: Effect of camel milk on the TCDD-mediated induction of Cyplal activity. Hepa 1c1c7 cells were treated for 24 with TCDD $(1 \mathrm{nM})$ in the presence and absence of camel milk $(0,25$, and $100 \mu \mathrm{L} / \mathrm{mL}$ ) or the positive control, resveratrol (Res, $25 \mu \mathrm{M}$ ). Cyplal activity was measured in intact living cells using EROD assay. Values are presented as mean $\pm \operatorname{SEM}(n=8) .{ }^{+} P<0.05$ compared with control (sterile water-treated cells), ${ }^{*} P<0.05$ compared with TCDD-treated cells.

TCDD significantly induced Cypla1 mRNA level by approximately 15-fold (Figure 3). Importantly, incubation of Hepa 1c1c7 cells with camel milk (fat-free) significantly decreased the TCDD-mediated induction of Cyplal mRNA in a concentration-dependent manner (Figure 3). The maximum inhibition (90\%) was observed at the highest concentration tested $(100 \mu \mathrm{L} / \mathrm{mL})$ (Figure 3$)$. Similar to Cyp1a1 activity, the positive control RES significantly decreased the TCDDmediated induction of Cypla1 mRNA (Figure 3).

3.4. Effect of Camel Milk on the TCDD-Mediated Induction of Cypla1 Protein in Hepa 1c1c7 Cells. To further investigate whether the obtained inhibition on TCDD-mediated induction of Cyp1a1 mRNA levels by camel milk is translated into a functional Cyplal protein, Western blot analysis was carried out. Total protein was isolated from Hepa 1c1c7 cells treated for $24 \mathrm{~h}$ with TCDD $(1 \mathrm{nM})$ in the presence and absence of different concentrations of camel milk (fat-free) $(0,25$, and $100 \mu \mathrm{L} / \mathrm{mL})$. Figure 4 shows that the induction of Cypla1 protein by TCDD (72-fold) was significantly reduced by camel milk (fat-free) by approximately $30 \%$ and $65 \%$ at concentrations of 25 and $100 \mu \mathrm{L} / \mathrm{mL}$, respectively. This pattern of inhibition is similar to what was observed at the activity and mRNA level (Figures 2 and 3 ).

Taken together, these results showed that camel milk stands prominently in its inhibition of the induction of Cyplal gene expression at the activity, mRNA, and protein levels.

3.5. Effect of Camel Milk on XRE-Dependent Luciferase Activity. To explore the ability of fat-free camel milk to inhibit the AhR-dependent reporter gene expression, Hepa 1clc7

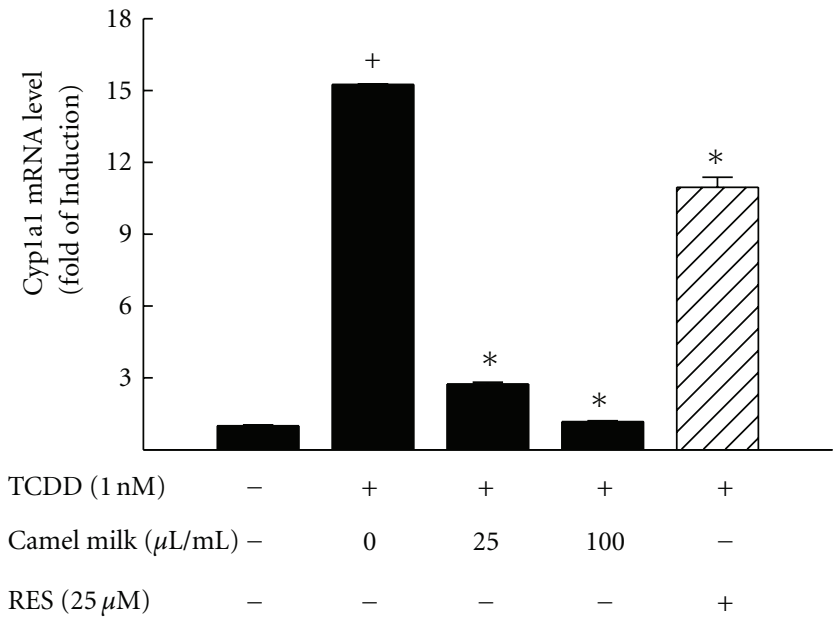

FIgure 3: Effect of camel milk on the TCDD-mediated induction of Cypla1 mRNA. Hepa 1c1c7 cells were treated for $6 \mathrm{~h}$ with TCDD $(1 \mathrm{nM})$ in the presence and absence of camel milk (fat-free) $(0,25$, and $100 \mu \mathrm{L} / \mathrm{mL}$ ) or the positive control, resveratrol (Res, $25 \mu \mathrm{M}$ ). The amount of Cypla1 mRNA was quantified using real-time PCR and normalized to $\beta$-actin housekeeping gene. Duplicate reactions were performed for each experiment, and the values represent mean of fold change \pm SEM. $(n=4) .{ }^{+} P<0.05$ compared with control (sterile water-treated cells), ${ }^{*} P<0.05$ compared with TCDDtreated cells.

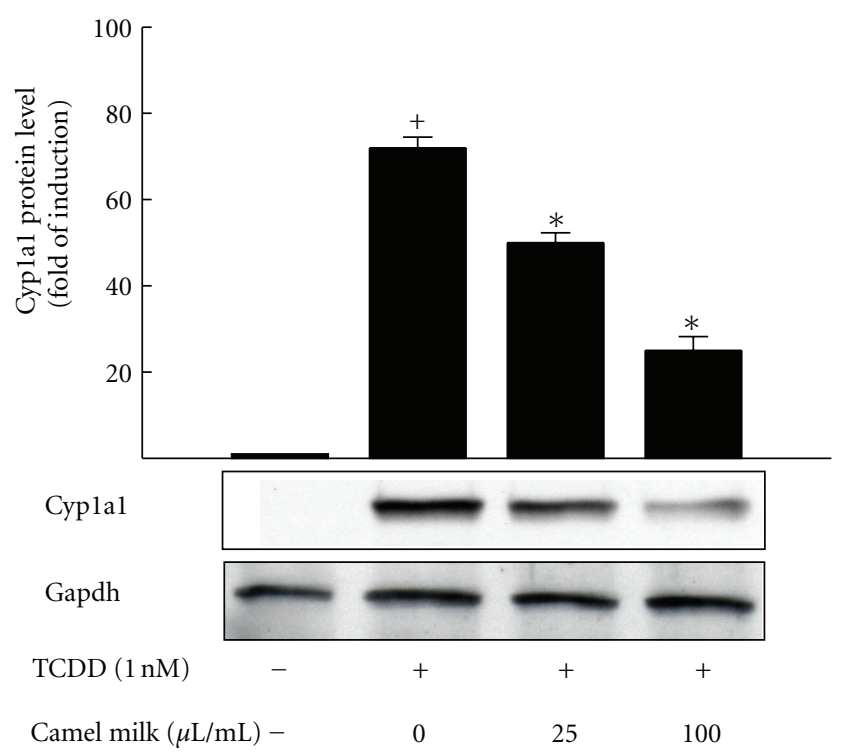

FIGURE 4: Effect of camel milk on the TCDD-mediated induction of Cyp 1a1 protein. Hepa 1c1c7 cells were treated for 24 with TCDD $(1 \mathrm{nM})$ in the presence and absence of camel milk (fat-free) $(0,25$, and $100 \mu \mathrm{L} / \mathrm{mL}$ ); thereafter, Cyplal protein level was determined by Western blot analysis and was detected using the enhanced chemiluminescence method. The intensity of Cyplal protein bands was quantified relative to the signals obtained for Gapdh protein, using ImageJ. One of the three representative experiments is shown and values represent mean of fold change \pm SEM. $(n=3) .{ }^{+} P<$ 0.05 compared with control (sterile water-treated cells), ${ }^{*} P<0.05$ compared with TCDD-treated cells. 


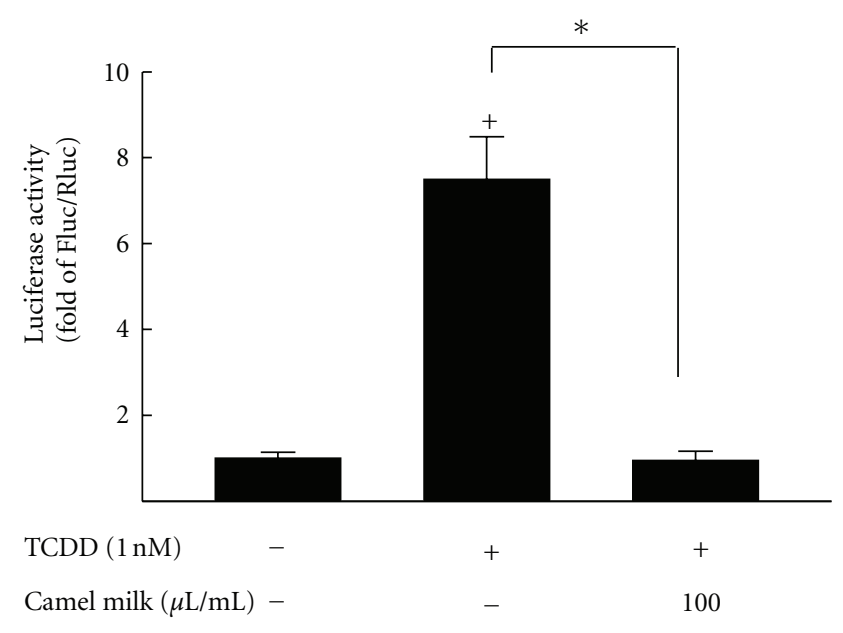

FIGURE 5: Effect of camel milk on XRE-dependent luciferase activity. Hepa 1c1c7 cells were transiently cotransfected with XRE-driven luciferase reporter plasmid pGudLuc 1.1. and renilla luciferase control plasmid pRL-CMV. Cells were treated with sterile water or camel milk (fat free, $100 \mu \mathrm{L} / \mathrm{mL}$ ) $30 \mathrm{~min}$ before the addition of TCDD ( $1 \mathrm{nM})$ for an additional $24 \mathrm{~h}$. Cells were lysed and luciferase activity was reported as relative light unit (RLU) of firefly luciferase to renilla luciferase (Fluc/Rluc) (mean \pm S.E.M., $n=4) .{ }^{+} P<0.05$ compared control (sterile water-treated cells), ${ }^{*} P<0.05$ compared with TCDD-treated cells.

cells were transiently cotransfected with the XRE-dependent luciferase reporter gene and renilla luciferase vector, which was used for normalization of transfection efficiency. Cells were then incubated for $24 \mathrm{~h}$ with TCDD (InM) in the presence and absence of camel milk $(100 \mu \mathrm{L} / \mathrm{mL})$. Our results showed that TCDD significantly induced XRE-dependent luciferase activity by approximately 7 -fold (Figure 5). Importantly, camel milk (fat-free, $100 \mu \mathrm{L} / \mathrm{mL}$ ) completely blocked the induction of XRE-dependent luciferase activity by TCDD to its control level (Figure 5 ).

3.6. Effect of Camel Milk on Ho-1 mRNA in Hepa 1c1c7 Cells. The capacity of camel milk to inhibit TCDD-mediated induction of Cyplal at the activity level more than at the protein levels prompted us to investigate the possible role of Ho-1, a rate-limiting enzyme of heme degradation, in this inhibitory effect. For this purpose, Ho-1 mRNA level was determined in Hepa 1c1c7 cells treated with increasing concentrations of camel milk $(0,25$, and $100 \mu \mathrm{L} / \mathrm{mL})$ or SFN $(5 \mu \mathrm{M})$, as a positive control, for $6 \mathrm{~h}$. Our results show that camel milk (fat-free) significantly increased the Ho-1 mRNA expression level by the highest concentration tested $(100 \mu \mathrm{L} / \mathrm{mL})$ by approximately 3 -fold (Figure 6$)$. Similarly, SFN caused a 9-fold induction in Ho-1 mRNA level. These data may suggest a role for Ho-1 in camel milk-mediated effects.

3.7. Effect of Camel Milk on Nqo1 and Gsta1 mRNA Levels in Hepa 1 c1c7 Cells. To further investigate whether camel milk

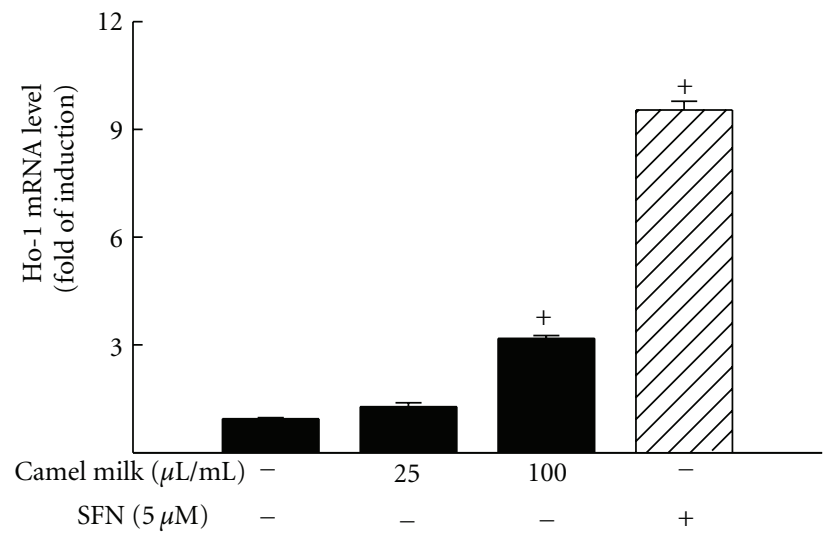

Figure 6: Effect of camel milk on Ho-1 mRNA expression level. Hepa $1 \mathrm{clc} 7$ cells were treated for $6 \mathrm{~h}$ with increasing concentrations of fat-free camel milk $(0,25$, and $100 \mu \mathrm{L} / \mathrm{mL})$ or SFN $(5 \mu \mathrm{M})$, as a positive control. The amount of Ho-1 mRNA was quantified using real-time PCR and normalized to $\beta$-actin housekeeping gene. Duplicate reactions were performed for each experiment, and the values represent mean of fold change \pm SEM. $(n=4) .{ }^{+} P<0.05$ compared with control (sterile water-treated cells).

(fat-free) is able to increase the expression of chemoprotective genes, Nqo1 and Gsta1 mRNA levels were measured in Hepa 1c1c7 cells treated for $6 \mathrm{~h}$ with camel milk $(0,25$, and $100 \mu \mathrm{L} / \mathrm{mL})$ or SFN $(5 \mu \mathrm{M})$, as a positive control. Figure 7 shows that camel milk (fat-free) significantly induced Nqo1 and Gstal mRNA levels by approximately 2.5 - and 8 -fold, respectively, at the highest concentration tested $(100 \mu \mathrm{L} / \mathrm{mL})$. A similar induction was observed with SFN, strong inducer of Nqo1 and Gstal (Figure 7).

3.8. Effect of Transcription Inhibitor, Act-D, on Camel-MilkInduced Nqo1 mRNA Levels. To further investigate whether camel milk (fat-free) is able to increase the de novo Nqo1 RNA synthesis, Hepa 1c1c7 cells were treated with Act-D ( $5 \mu \mathrm{g} / \mathrm{mL}$, RNA synthesis inhibitor) immediately before the addition of camel milk (fat-free, $100 \mu \mathrm{L} / \mathrm{mL}$ ) for additional $6 \mathrm{~h}$. Thereafter, Nqo1 mRNA was quantified by real-time PCR. If camel milk increases the amount of Nqo1 mRNA through a transcriptional mechanism, a decrease in the Nqo1 mRNA level would be expected. Figure 8 shows that Act-D slightly but significantly inhibited the constitutive expression of Nqo1 mRNA, whereas markedly blocked the camel milkinduced Nqo1 mRNA by approximately 70\% (Figure 8).

\section{Discussion}

The current study provides the first mechanistic evidence of the ability of camel milk to significantly inhibit the induction of Cyp1a1, a cancer-activating gene, and to induce Nqo1 and Gstal, cancer protecting genes in Hepa 1c1c7 cells at the transcriptional and posttranscriptional levels.

One of the strategies for protecting human cells and tissues from the toxic effects of carcinogenic and cytotoxic metabolites include attenuation of the carcinogen-activating 


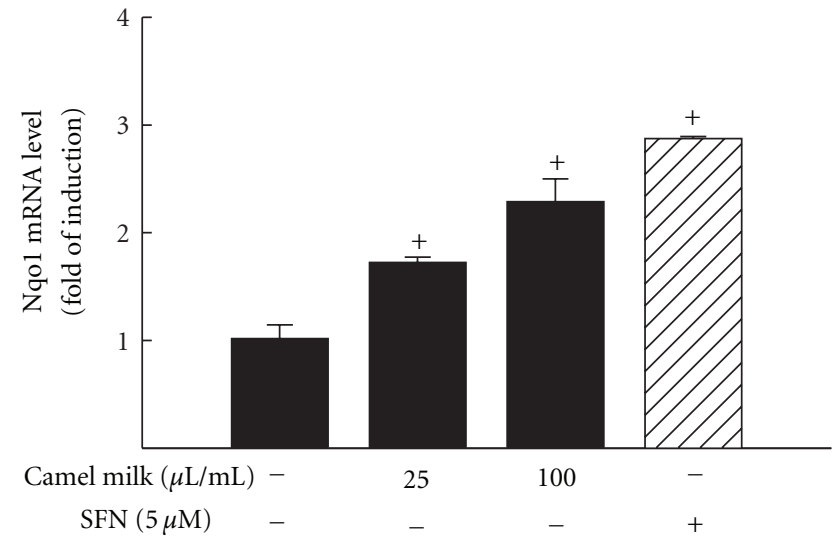

(a)

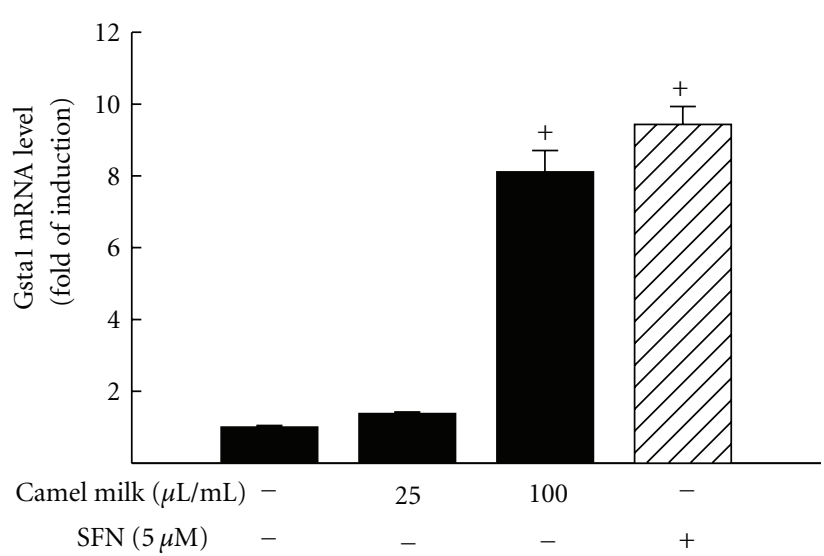

(b)

FIGURE 7: Effect of camel milk on Nqo1 (a) and Gstal (b) mRNA expression levels. Hepa 1clc7 cells were treated for 6 h with fat-free camel milk $(0,25$, and $100 \mu \mathrm{L} / \mathrm{mL})$ or SFN $(5 \mu \mathrm{M})$, as a positive control. The amount of Nqo1 and Gstal mRNA levels was quantified using realtime PCR and normalized to $\beta$-actin housekeeping gene. Duplicate reactions were performed for each experiment and the values represent mean of fold change \pm SEM. $(n=4) .{ }^{+} P<0.05$ compared with control (sterile water-treated cells).

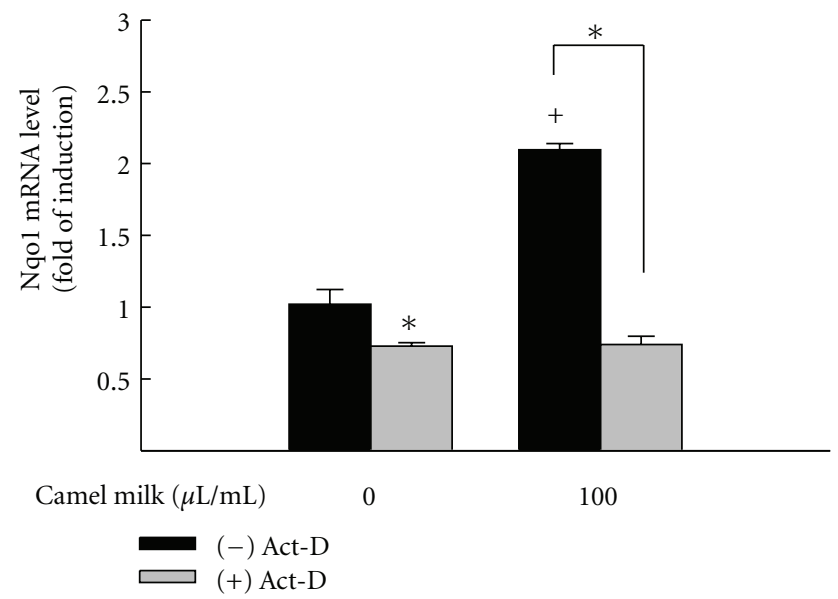

FIGURE 8: Effect of transcription inhibitor, Act-D, on the induction of Nqo1 mRNA by camel milk. Hepa 1clc7 cells were incubated with the transcription inhibitor, Act-D $(5 \mu \mathrm{g} / \mathrm{mL})$, immediately before the addition of fat-free camel milk $(100 \mu \mathrm{L} / \mathrm{mL})$ for $6 \mathrm{~h}$. The amount of Nqo1 mRNA was quantified using real-time PCR and normalized to $\beta$-actin housekeeping gene. Duplicate reactions were performed for each experiment, and the values represent mean of fold change \pm SEM. $(n=4) .{ }^{+} P<0.05$ compared with control (sterile water-treated cells), ${ }^{*} P<0.05$ compared with corresponding treatment in the absence of Act-D.

genes signaling pathways and/or enhancing the adaptive mechanisms by increasing the expression of detoxification and antioxidant genes. Accordingly, we hypothesize that camel milk exhibits anticancer effects by inhibiting the expression of Cyplal and/or inducing Nqol and Gstal genes. Therefore, to test our hypothesis we examined the capacity of camel milk to (a) inhibit the induction of Cypla1 at the mRNA, protein, and activity levels, (b) induce the expression of Nqo1, and Gsta1 mRNA levels in Hepa 1c1c7 cells, and (c) explore the underlying molecular mechanism.

Several lines of evidence showed that induction of CYP1A1 is strongly correlated with increased incidence of several human colon, rectal, and lung cancers $[23,24]$. In addition, studies on the carcinogenicity and mutagenicity of PAHs have demonstrated a significant role for the induction of CYP1A1 in bioactivating these environmental toxicants into their ultimate carcinogenic forms [25]. Thus Cyplal induction is considered a useful biomarker of exposure to carcinogenic substances [26]. Accordingly, we have first examined the potential effect of camel milk on the expression of Cyplal gene after induction by TCDD using EROD as a probe for Cyplal activity [27]. Our results showed that camel milk (fat-free) at all concentrations tested reduced Cypla1 EROD activity in a concentrationdependent manner (Figure 2). Importantly, the modulation of Cypla1 activity by camel milk is attributed to a decrease in transcriptional and translational regulation of Cypla1 gene. This was evidenced by the ability of camel milk to alter the expression of Cyplal at the mRNA and protein levels (Figures 3 and 4).

The transcriptional regulation of Cypla1 and Nqo1 genes by camel milk (fat-free) was demonstrated by several lines of evidence. First, the inhibition of XRE-dependent luciferase assay that occurs only through the AhR activation suggests an AhR-dependent transcriptional control (Figure 5). Second, the ability of the transcription inhibitor, Act-D, to significantly block the newly synthesized Nqo1 mRNA (Figure 7) suggests a requirement of de novo RNA synthesis for the induction of Nqo1 mRNA by camel milk. Taken together, these results strongly suggest that the inhibition of Cypla1 and induction of Nqol genes by camel milk is mediated, at least in part, at the transcriptional level.

Interestingly, the observation that camel milk-mediated inhibition of Cyplal induction by TCDD at the activity 
levels is higher than those observed at the protein levels (Figure 2), suggest that a possible involvement of a posttranslational mechanism, such as phosphorylation, proteasomal degradations, modulation of HO-1 gene expression, could be involved $[22,28]$. Among these mechanisms, HO-1 gene expression, a rate-limiting enzyme in heme catabolism, has been shown to alter cellular heme, the prosthetic group of CYP450, content and hence the enzyme activity [29]. To test this hypothesis, we have examined the effect of camel milk (fat-free) on the expression of Ho1 mRNA level. Our results showed that the camel milk increases the level of Ho-1 mRNA levels (Figure 6). Taken together, we postulated here that the capacity of camel milk to induce the expression of Ho-1 mRNA resulted in a decrease in Cypla1 activity levels through degrading its heme content. This postulation is supported by our previous observations that in mesoporphyrin, competitive Ho-1 inhibitor or knockdown of Ho-1 using siRNA significantly restored the inhibition of Cyplal activity by heavy metals $[30,31]$.

The chemo protective effect of camel milk was further supported, in addition to inhibition of Cypla1, by the ability to upregulate antioxidant genes, particularly $\mathrm{Nqo} 1$ and Gstal mRNA levels in a concentration-dependent manner (Figure 7). Our results are in agreement with previous studies that reported the ability of camel milk to induce GST levels in healthy and schistosoma-infected mice [32]. Thus increased expression of Nqo1 and Gstal by camel milk will increase the levels of several antioxidant enzymes which prevent the formation of highly reactive oxygen radicals and hence reduce DNA adduct and cell damage [33]. In addition, overexpression of NQO1 in several human solid tumors and cancer cells has been shown to activate bioreductive chemotherapeutic agents in tumor cells that allow tumor cytotoxicity without corresponding toxicity to normal cells [34].

Although the potential mediators in camel milk involved in the downregulation of Cypla1 and induction of Nqo1 and Gstal were not examined in this study, several previous studies have reported that camel milk contains considerably higher amounts of antioxidant vitamins, such as E and C, in comparison to cow milk [35], lysosomes [11], lactoferrins $[11,36]$, and immunoglobulines [36]. In addition, ongoing research in our laboratory has shown the presence of several compounds in camel milk that could be involved in milkmediated effect (unpublished data). Among these mediators, lactoferrin, an iron-binding glycoprotein, is known to exert in vitro and in vivo antitumor activity [37]. In this context, it has been recently reported that lactoferrin inhibits the development of cancer through inhibiting CYP1A1 activation in 7,12-dimethylbenz[a] anthracene- (DMBA-) induced hamster buccal pouch carcinoma model. Taken together the results obtained from our laboratory and previously published reports, we speculate that lactoferrin could be responsible for camel-milk-mediated effect. In addition, the main components of the camel milk have been already determined [38]. Ongoing research in our laboratory focuses on identifying and characterizing the most effective component of camel milk using liquid chromatography-tandem mass spectrometry (LC-MS/MS) and one-dimensional gel electrophoresis, where several proteins were found to be relatively abundant in camel milk (data not shown).

In conclusion, the results of current study suggest that camel milk could protect against or decrease the deleterious effects of many environmental toxicants and carcinogens such as PAHs, probably through modulation of AhR-regulated genes of Cyp1a1, Nqo1, and Gsta1 at the transcriptional and posttranscriptional mechanisms. These results are of potential clinical significance to humans in that it uncovers the molecular mechanism involved and could explain the anecdotal evidence for the successful use of camel milk in the treatment and/or prevention of various medical conditions.

\section{Abbreviations}

AhR: Aryl hydrocarbon receptor

Act-D: Actinomycin D

CYP1A1: Cytochrome P450 1A1

DMSO: Dimethyl sulfoxide

7ER: 7-ethoxyresorufin

EROD: 7-ethoxyresorufin O-deethylase

Gapdh: Glyceraldehyde-3-phosphate dehydrogenase.

Gsta1: Glutathione S-transferase a1

MTT: (3-(4,5-dimethylthiazol-2-yl)-2,5-diphenyl tetrazolium bromide)

Nqo1: $\quad \mathrm{NAD}(\mathrm{P}) \mathrm{H}$ :quinone oxidoreductase

PAHs: Polycyclic aromatic hydrocarbons

RES: Resveratrol

SFN: Sulforaphane

TCDD: 2,3,7,8-tetrachlorodibenzo- $p$-dioxin

XRE: Xenobiotic responsive element.

\section{Conflict of Interests}

The authors declare that there is no conflict of interests.

\section{Acknowledgments}

The authors extend their appreciation to the Deanship of Scientific Research at King Saud University for funding the work through the research group project no. RGP-VPP-141.

\section{References}

[1] J. K. Kerzee and K. S. Ramos, "Constitutive and inducible expression of Cypla1 and Cyplb1 in vascular smooth muscle cells: role of the Ahr bHLH/PAS transcription factor," Circulation Research, vol. 89, no. 7, pp. 573-582, 2001.

[2] M. L. Whitelaw, M. Gottlicher, J. A. Gustafsson, and L. Poellinger, "Definition of a novel ligand binding domain of a nuclear bHLH receptor: co-localization of ligand and hsp90 binding activities within the regulable inactivation domain of the dioxin receptor," EMBO Journal, vol. 12, no. 11, pp. 41694179, 1993.

[3] J. P. Whitlock Jr., "Induction of cytochrome P4501A1," Annual Review of Pharmacology and Toxicology, vol. 39, pp. 103-125, 1999. 
[4] D. W. Nebert, A. L. Roe, M. Z. Dieter, W. A. Solis, Y. Yang, and T. P. Dalton, "Role of the aromatic hydrocarbon receptor and [Ah] gene battery in the oxidative stress response, cell cycle control, and apoptosis," Biochemical Pharmacology, vol. 59, no. 1, pp. 65-85, 2000.

[5] D. W. Nebert, T. P. Dalton, A. B. Okey, and F. J. Gonzalez, "Role of aryl hydrocarbon receptor-mediated induction of the CYP1 enzymes in environmental toxicity and cancer," Journal of Biological Chemistry, vol. 279, no. 23, pp. 23847-23850, 2004.

[6] D. Ross, "Quinone reductases multitasking in the metabolic world," Drug Metabolism Reviews, vol. 36, no. 3-4, pp. 639654, 2004.

[7] V. Vasiliou, D. Ross, and D. W. Nebert, "Update of the $\mathrm{NAD}(\mathrm{P}) \mathrm{H}$ :Quinone oxidoreductase (NQO) gene family," Human Genomics, vol. 2, no. 5, pp. 329-335, 2006.

[8] M. Cuendet, C. P. Oteham, R. C. Moon, and J. M. Pezzuto, "Quinone reductase induction as a biomarker for cancer chemoprevention," Journal of Natural Products, vol. 69, no. 3, pp. 460-463, 2006.

[9] N. Kontou, T. Psaltopoulou, D. Panagiotakos, M. A. Dimopoulos, and A. Linos, "The mediterranean diet in cancer prevention: a review," Journal of Medicinal Food, vol. 14, no. 10, pp. 1065-1078, 2011.

[10] C. Conesa, L. Sánchez, C. Rota et al., "Isolation of lactoferrin from milk of different species: calorimetric and antimicrobial studies," Comparative Biochemistry and Physiology B, vol. 150, no. 1, pp. 131-139, 2008.

[11] E. I. el Agamy, R. Ruppanner, A. Ismail, C. P. Champagne, and R. Assaf, "Antibacterial and antiviral activity of camel milk protective proteins," Journal of Dairy Research, vol. 59, no. 2, pp. 169-175, 1992.

[12] C. Saravanan, Z. Cao, J. Kumar et al., "Milk components inhibit Acanthamoeba-induced cytopathic effect," Investigative Ophthalmology \& Visual Science, vol. 49, no. 3, pp. 10101015, 2008.

[13] H. M. Korashy and A. O. S. El-Kadi, "The role of aryl hydrocarbon receptor and the reactive oxygen species in the modulation of glutathione transferase by heavy metals in murine hepatoma cell lines," Chemico-Biological Interactions, vol. 162, no. 3, pp. 237-248, 2006.

[14] S. W. Kennedy, A. Lorenzen, C. A. James, and B. T. Collins, "Ethoxyresorufin-O-deethylase and porphyrin analysis in chicken embryo hepatocyte cultures with fluorescence multiwell plate reader," Analytical Biochemistry, vol. 211, no. 1, pp. 102-112, 1993.

[15] A. Lorenzen and S. W. Kennedy, "A fluorescence-based protein assay for use with a microplate reader," Analytical Biochemistry, vol. 214, no. 1, pp. 346-348, 1993.

[16] B. N. M. Zordoky, M. E. Aboutabl, and A. O. S. ElKadi, "Modulation of cytochrome P450 gene expression and arachidonic acid metabolism during isoproterenol-induced cardiac hypertrophy in rats," Drug Metabolism and Disposition, vol. 36, no. 11, pp. 2277-2286, 2008.

[17] A. Anwar-Mohamed, O. S. Degenhardt, M. A. M. El Gendy, J. M. Seubert, S. R. Kleeberger, and A. O. S. El-Kadi, "The effect of Nrf2 knockout on the constitutive expression of drug metabolizing enzymes and transporters in C57Bl/6 mice livers," Toxicology in Vitro, vol. 25, no. 4, pp. 785-795, 2011.

[18] A. Anwar-Mohamed, R. H. Elbekai, and A. O. S. El-Kadi, "MG-132 inhibits the TCDD-mediated induction of Cypla1 at the catalytic activity but not the mRNA or protein levels in Hepa 1c1c7 cells," Toxicology Letters, vol. 182, no. 1-3, pp. 121126, 2008.
[19] K. J. Livak and T. D. Schmittgen, "Analysis of relative gene expression data using real-time quantitative PCR and the 2$\Delta \Delta$ CT method," Methods, vol. 25, no. 4, pp. 402-408, 2001.

[20] J. Sambrook, E. F. Fritsch, and T. Maniatatis, "Molecular Cloning," in A Laboratory Manual, N. Ford, Ed., Cold Spring Harbour Laboratory Press, Plainview, NY, USA, 1989.

[21] M. A. M. El Gendy, A. A. Soshilov, M. S. Denison, and A. O. S. El-Kadi, "Transcriptional and posttranslational inhibition of dioxin-mediated induction of CYP1A1 by harmine and harmol," Toxicology Letters, vol. 208, no. 1, pp. 51-61, 2012.

[22] H. M. Korashy and A. O. S. El-Kadi, "Regulatory mechanisms modulating the expression of cytochrome P450 1A1 gene by heavy metals," Toxicological Sciences, vol. 88, no. 1, pp. 39-51, 2005.

[23] M. L. Slattery, W. Samowtiz, K. Ma et al., "CYP1A1, cigarette smoking, and colon and rectal cancer," American Journal of Epidemiology, vol. 160, no. 9, pp. 842-852, 2004.

[24] P. P. Shah, K. Saurabh, M. C. Pant, N. Mathur, and D. Parmar, "Evidence for increased cytochrome P450 1A1 expression in blood lymphocytes of lung cancer patients," Mutation Research - Fundamental and Molecular Mechanisms of Mutagenesis, vol. 670, no. 1-2, pp. 74-78, 2009.

[25] T. Shimada and Y. Fujii-Kuriyama, "Metabolic activation of polycyclic aromatic hydrocarbons to carcinogens by cytochromes P450 1A1 and 1B1," Cancer Science, vol. 95, no. 1, pp. 1-6, 2004.

[26] T. D. Williams, J. S. Lee, D. L. Sheader, and J. K. Chipman, "The cytochrome P450 1A gene (CYP1A) from European flounder (Platichthys flesus), analysis of regulatory regions and development of a dual luciferase reporter gene system," Marine Environmental Research, vol. 50, no. 1-5, pp. 1-6, 2000.

[27] B. Hasspieler, D. Haffner, M. Stelljes, and K. Adeli, "Toxicological assessment of industrial solvents using human cell bioassays: assessment of short-term cytotoxicity and longterm genotoxicity potential," Toxicology and Industrial Health, vol. 22, no. 7, pp. 301-315, 2006.

[28] V. Werlinder, M. Backlund, A. Zhukov, and M. IngelmanSundberg, "Transcriptional and post-translational regulation of CYP1A1 by primaquine," Journal of Pharmacology and Experimental Therapeutics, vol. 297, no. 1, pp. 206-214, 2001.

[29] G. Kikuchi, T. Yoshida, and M. Noguchi, "Heme oxygenase and heme degradation," Biochemical and Biophysical Research Communications, vol. 338, no. 1, pp. 558-567, 2005.

[30] I. E. A. Amara, A. Anwar-Mohamed, and A. O. S. ElKadi, "Mercury modulates the CYP1A1 at transcriptional and posttranslational levels in human hepatoma HepG2 cells," Toxicology Letters, vol. 199, no. 3, pp. 225-233, 2010.

[31] A. Anwar-Mohamed and A. O. S. El-Kadi, "Arsenite downregulates cytochrome $\mathrm{P} 450 \mathrm{AA} 1$ at the transcriptional and posttranslational levels in human HepG2 cells," Free Radical Biology and Medicine, vol. 48, no. 10, pp. 1399-1409, 2010.

[32] A. S. Maghraby, M. A. Mohamed, and A. M. Abdel-Salam, "Anti-schistosomal activity of colostral and mature camel milk on Schistosoma mansoni infected mice," Asia Pacific Journal of Clinical Nutrition, vol. 14, no. 4, pp. 432-438, 2005.

[33] M. Mohora, "Role of $\mathrm{Nad}(\mathrm{P}) \mathrm{h}$ : quinone oxidoreductase in the regulation of intracellular redox state," Romanian Journal of Internal Medicine, vol. 38-39, pp. 33-50, 2000.

[34] S. Danson, T. H. Ward, J. Butler, and M. Ranson, "DTdiaphorase: a target for new anticancer drugs," Cancer Treatment Reviews, vol. 30, no. 5, pp. 437-449, 2004.

[35] Z. Farah, R. Rettenmaier, and D. Atkins, "Vitamin content of camel milk," International Journal for Vitamin and Nutrition Research, vol. 62, no. 1, pp. 30-33, 1992. 
[36] G. Konuspayeva, B. Faye, G. Loiseau, and D. Levieux, "Lactoferrin and immunoglobulin contents in camel's milk (Camelus bactrianus, Campus dromedarius, and Hybrids) from Kazakhstan," Journal of Dairy Science, vol. 90, no. 1, pp. 38-46, 2007.

[37] A. Roseanu, P. E. Florian, M. Moisei, L. E. Sima, R. W. Evans, and M. Trif, "Liposomalization of lactoferrin enhanced its anti-tumoral effects on melanoma cells," BioMetals, vol. 23, no. 3, pp. 485-492, 2010.

[38] M. S. Y. Haddadin, S. I. Gammoh, and R. K. Robinson, "Seasonal variations in the chemical composition of camel milk in Jordan," Journal of Dairy Research, vol. 75, no. 1, pp. $8-12,2008$. 

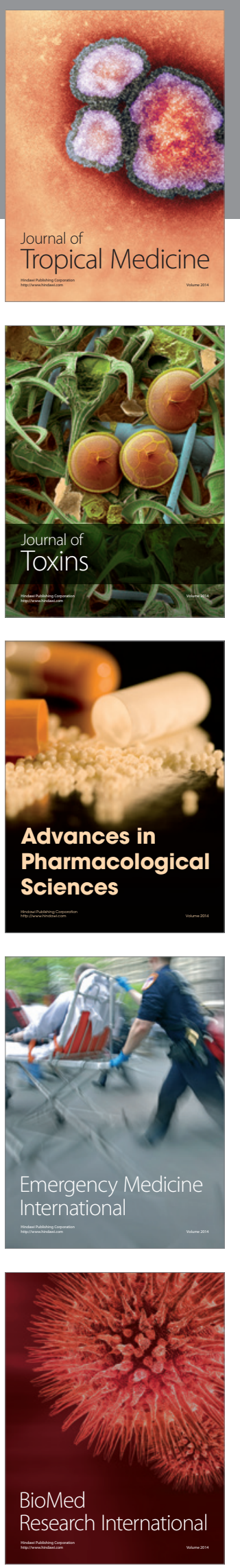
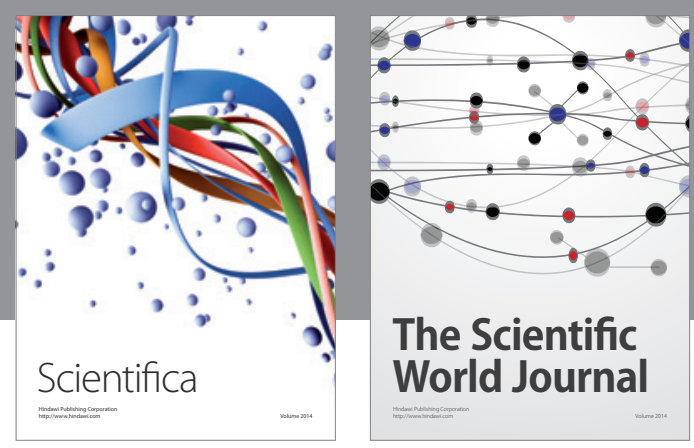

The Scientific World Journal
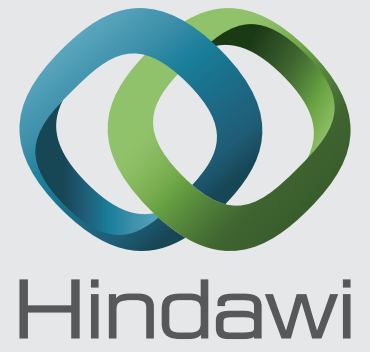

Submit your manuscripts at

http://www.hindawi.com
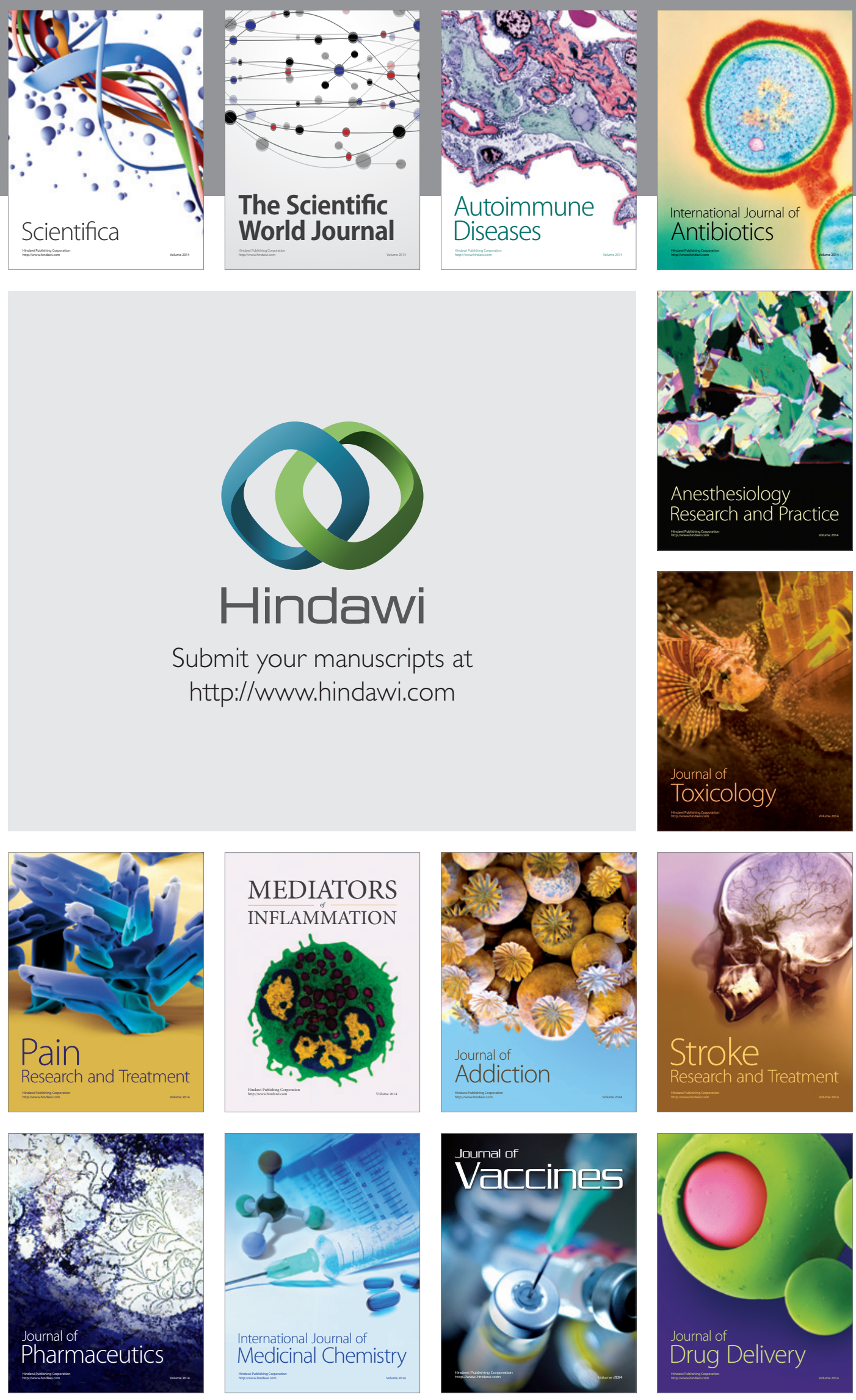